\title{
The Number of Variants in the Greek New Testament: A Proposed Estimate
}

\author{
PETER J. GURRY \\ Fitzwilliam College, University of Cambridge \\ 36 Selwyn Gardens, Cambridge, $\mathrm{CB}_{3}$ 9BA, UK \\ Email:pg412@cam.ac.uk
}

\begin{abstract}
Since the publication of John Mill's Greek New Testament in 1707, scholars have shown repeated interest in the number of textual variants in our extant witnesses. Past estimates, however, have failed to tell who estimated, how the estimate was derived, or even what was being estimated. This study addresses all three problems and so offers an up-to-date estimate based on the most extensive collation data available. The result is a higher number than almost all previous estimates. But careful comparison shows that this number reflects the frequency with which scribes copied more than their infidelity in doing so.
\end{abstract}

Keywords: textual criticism, transmission of the New Testament, number of variants

\section{INTRODUCTION}

In June of 1707 John Mill, fellow of Queen's College, Oxford, published his Greek New Testament. The labor of the previous 30 years of his life, Mill's edition was published just two weeks before his death. The text of Mill's edition is of no particular importance, being as it was a mere reprinting of Stephanus's $155^{\circ}$ text. What was noteworthy was what lay beneath it. In his 30 years of work, Mill had managed to collect an estimated 30,000 variants among the witnesses. It was these variants that became the cause of some controversy in the years that followed. Some felt that the presence of so many differences would render the text and therefore the authority of the New Testament insecure. ${ }^{1}$ It was Richard Bentley, the Master of Trinity College, Cambridge, who offered the most substantial response to these concerns in his Remarks upon a Late Discourse of Free-Thinking first published in 1713 and surviving through eight editions. It was Bentley who pointed out the connection between the number of manuscripts and the number of variants writing that 'if more copies are collated, the sum will mount higher' and that 'the more copies you call to assistance, the more do the various readings multiply upon you. ${ }^{2}$

Three hundred years after Bentley penned these words, the number of known copies of the New Testament has increased significantly. Whereas Mill's edition had access to less than 100 Greek manuscripts, the Institut für Neutestamentliche Textforschung (INTF) in Münster, Germany currently catalogs over

\footnotetext{
${ }^{1}$ The story is recounted in Adam Fox, John Mill and Richard Bentley: A Study of the Textual Criticism of the New Testament $1675-$ 1729 (Oxford: Basil Blackwell, 1954) 105-15.

${ }^{2}$ Richard Bentley, 'Remarks upon a Late Discourse of Free-Thinking,' The Works of Richard Bentley (ed. Alexander Dyce; 3 vols.; London: Robson, Levey, and Franklyn, 1838) III.349, III.350.
} 
5,60o. ${ }^{3}$ Despite this fifty-six-fold increase, the actual sum of variants which Bentley referenced has not risen at the same rate for the simple (but sometimes forgotten) reason that 'no one has yet been able to count them all. ${ }^{4}$ Instead, what has increased steadily since Bentley and Mill are estimates about the total number of variants in the New Testament.

One finds these estimates across the literature, in New Testament introductions, exegetical handbooks, and especially in textbooks on textual criticism. The purpose is almost always to raise awareness about the need for textual criticism. Sometimes the point is made with more pessimism, as when Günther Zuntz, for example, says that the total is an 'unimaginable and unmanageable mass.' In still other cases, the estimate plays the same role it played in Mill's day: causing concern for some and thus requiring a response from others. ${ }^{6}$ In some cases, attempts to put these estimates in perspective leads to surprising conclusions about the overall transmission of the New Testament text as when Stanley Porter suggests that ancient manuscript production 'nearly rivals that sometimes found today in modern print' or when Craig Blomberg suggests that there may be as few as eight variants per manuscript. ${ }^{7}$

Despite the continuing appeal of such estimates, Eldon Epp is right that 'there is, however, no reliable estimate of the total number of variants found in our extant witnesses. ${ }^{8}$ The present essay hopes to provide just such an estimate while offering a few brief comments on how such an estimate might be put to good use. Before turning to our own estimate, it will be useful to trace briefly the estimates that have been offered in the past and to demonstrate something of their inadequacy.

\section{PAST ESTIMATES \& THEIR PROBLEMS}

\subsection{Survey of Estimates}

A survey of books and articles from last 150 years shows how frequently such estimates are appealed to (for a survey, see 6). The starting point—or at least the point of comparison-for many of these estimates is the

\footnotetext{
${ }^{3}$ For a list of manuscripts available to Mill, see Fox, Mill and Bentley, 143-6. The list kept by INTF is available at http://ntvmr.uni-muenster.de/liste. At the time of writing, the numbers are 127 papyri, 286 majuscules, 2,841 minuscules, and 2,384 lectionaries.

${ }^{4}$ Bart D. Ehrman, 'Text and Interpretation: The Exegetical Significance of the 'Original' Text,' Studies in the Textual Criticism of the New Testament (NTTS 33; Leiden: Brill, 2006) 309; originally published as Bart D. Ehrman, 'Text and Interpretation: The Exegetical Significance of the "Original” Text,' TC: A Journal of Biblical Textual Criticism (20oo) available at http://rosetta.reltech.org/TC/vo5/Ehrman20ooa.html (accessed September 22, 2014). No estimate today 'represents the sum total of all analyzed manuscripts' as claimed by K. Martin Heide in 'Assessing the Stability of the Transmitted Texts of the New Testament and the Shepherd of Hermas,' The Reliability of the New Testament: Bart D. Ehrman and Daniel B. Wallace in Dialogue (ed. Robert B. Stewart; Minneapolis: Fortress, 2011) 157.

${ }^{5}$ Günther Zuntz, The Text of the Epistles: A Disquisition upon the Corpus Paulinum (Schweich Lectures 1946; London: Oxford University Press, 1953) 58.

${ }^{6}$ See especially Bart D. Ehrman and Daniel B. Wallace, 'The Textual Reliability of the New Testament: A Dialogue,' The Reliability of the New Testament: Bart D. Ehrman and Daniel B. Wallace in Dialogue (ed. Robert B. Stewart; Minneapolis: Fortress, 2011) 13-6o, esp. 21-2, 32-4; Daniel B. Wallace, 'Lost in Transmission: How Badly Did the Scribes Corrupt the New Testament Text?', Revisiting the Corruption of the New Testament: Manuscript, Patristic, and Apocryphal Evidence (Grand Rapids: Kregel, 2011) 26-40.

${ }^{7}$ Stanley E. Porter, How We Got the New Testament: Text, Transmission, Translation (Grand Rapids: Baker Academic, 2013) 66; Craig L. Blomberg, Can We Still Believe the Bible? An Evangelical Engagement with Contemporary Questions (Grand Rapids: Brazos, 2014) 17 .

${ }^{8}$ Eldon Jay Epp, 'Why Does New Testament Textual Criticism Matter? Refined Definitions and Fresh Directions,' ExpT 125, no. $9(2014) 419$.
} 
estimated 30,000 variants in Mill's edition. ${ }^{9}$ One of the first attempts to update the estimate is found in F. H. A. Scrivener's Plain Introduction first published in 1861. After making the same point as Bentley about more manuscripts producing more variants, Scrivener suggests that, if Mill found 30,000 variants in his day, then the total number 'must at present amount to at least fourfold that quantity' $(=120,000) .^{10}$ Although he gives no rationale for his degree of increase, his estimate was picked up by others and even enlarged soon afterward by Philip Schaff who wrote in 1883 that the number 'now cannot fall much short of 150,00o, if we include the variations in the order of words, the mode of spelling, and other trifles which are ignored even in the most extensive critical editions." The qualification Schaff attaches to his own increase highlights the importance of definitions, a point we will return to in due course.

The next jump in the estimate comes from B. B. Warfield of Princeton who adds yet another 30,000+ variants. ${ }^{12}$ Writing just six years after Schaff, Warfield claims that 'roughly speaking, there have been counted in it [the New Testament] some hundred and eighty or two hundred thousand "various readings" - that is, actual variations of reading in existing documents. ${ }^{13}$ Aside from its claim to present a 'count' rather than an 'estimate,' Warfield's number is worth noting both because he is the first to offer an explanation of how the count was done but even more so because the explanation he gives is so strange. Rather than a count of the number of differences among manuscripts, Warfield actually offers us a count of the number of manuscripts that differ from an unstated standard of comparison. The count, he tells us, is conducted in such a way that 'each place where a variation occurs is counted as many times over, not only as distinct variations occur upon it, but also as the same variation occurs in different manuscripts. ${ }^{, 14}$ This would mean that if 100 manuscripts agreed against the standard, the result would be 100 variants.

Over the next 45 years, the estimates range between Scrivener's and Warfield's with the trend toward Warfield's higher numbers, despite his odd way of 'counting.' Ezra Abbot suggested 150,000 in 1891, Eberhard Nestle gave 120,000-150,000 in 1897, and Marvin Vincent gave 150,000-200,000 two years later. ${ }^{15}$ Only Adolf Jülicher gave a lower number, suggesting either 30,000 or 100,000 but felt that the choice made no theological difference since the church has never had an errorless copy from which to work. ${ }^{16}$ By 1915 , Charles Sitterly offered Warfield's upper limit alone $(200,000)$ though he makes clear that he is not just thinking of the Greek manuscripts. ${ }^{17}$

\footnotetext{
${ }^{9}$ It is sometimes not appreciated that this number was not offered by Mill himself and is itself an estimate made by Gerard von Maestricht in the prolegomena to his 1711 edition of the Greek New Testament (Fox, Mill and Bentley, 105).

${ }^{10}$ F. H. A. Scrivener, A Plain Introduction to the Criticism of the New Testament for the Use of Biblical Students (Cambridge: Deighton, $\left.1861^{1}\right) 3$.

${ }^{11}$ Philip Schaff, A Companion to the Greek Testament and the English Version (New York: Harper \& Brothers, 1883 ) 176.

${ }^{12}$ Eldon Epp has recently written that 'in 1882, Hort spoke of 300,000 variants in the known witnesses,' but I can find no evidence for this claim. See Eldon Jay Epp, 'Textual Criticism and New Testament Interpretation,' Method and Meaning: Essays on New Testament Interpretation in Honor of Harld W. Attridge (ed. Andrew B. McGowan and Kent H. Richards; Resources for Biblical Study 67; Atlanta: SBL, 2011) 87; cf. Epp, 'Why Does New Testament Textual Criticism Matter?', 419.

${ }^{13}$ B. B. Warfield, An Introduction to the Textual Criticism of the New Testament (London: Hodder \& Stoughton, 1889) 13.

${ }^{14}$ Warfield, Introduction, 13 (emphasis mine). The same way of counting is still found, for example, in Neil R. Lightfoot, How We Got the Bible, (Grand Rapids: Eerdmans, $2003^{3}$ ) 96: 'If one slight variant were to occur in 4,0oo different manuscripts, this would amount to 4,000 "errors."

${ }^{15}$ Ezra Abbot, C. von Tischendorf, and O. von Gebhardt, 'Bible Text-New Testament,' A Religious Encyclopaedia or Dictionary of Biblical, Historical, Doctrinal, and Practical Theology (ed. Philip Schaff; 4 vols.; New York: Funk \& Wagnalls, 1891) I.278; Eberhard Nestle, Einführung in das Griechische Neue Testament (Göttingen: Vandenhoeck und Ruprecht, 1897 ${ }^{1}$ ) 14; Marvin R. Vincent, A History of the Textual Criticism of the New Testament (London: Macmillan, 1899) 6.

${ }^{16}$ Adolf Jülicher, An Introduction to the New Testament (London: Smith, Elder \& Co., 1904) 589-90.

${ }^{17}$ Charles F. Sitterly, 'Text and MSS (NT),' The International Standard Bible Encyclopedia (ed. James Orr; 5 vols.; Chicago: Howard-Severance, 1915) V.2,955.
} 
In 1934, the estimate makes its next major jump in both Louis Pirot and Léon Vaganay who put the estimate as high as $25^{0,000 .}{ }^{18}$ Pirot, we should note is the first to point out that there are probably more variants than words in the New Testament. Another 15 years adds another 50,000 variants to the estimate when Erwin Nestle gives 250,000-300,000 in 1951, and this just in the Greek manuscripts according to him. ${ }^{19}$

Almost 100 years after Scrivener, we find only the second estimate after von Maestricht's estimate of Mill that is based on explicit data. With the work of the International Greek New Testament Project (IGNTP) on Luke, Kenneth Clark wrote in 1966 that scholars can now 'estimate more accurately the scope and character of the textual condition of the Greek NT. ${ }^{20}$ Using these data, Merrill Parvis concluded that the actual number is perhaps much higher than previous estimates of 150,000-250,000 and Kenneth Clark made clear just how much higher with his own estimate of $300,000 .{ }^{21}$ Following this, older estimates continue to be cited in the literature, but Clark's 300,000 variants slowly begin to dominate. This number is cited, for example, in essays and books by J. K. Elliott and Ian Moir, Eldon Epp, Bart Ehrman, and Eckhard Schnabel. ${ }^{22}$ But like all such estimates, this one too was not to last long.

In 2007, Eldon Epp rounded up his previously-cited 300,000 variants to one-third of a million, but it was Bart Ehrman, in his bestselling Misquoting Jesus, who is the first to suggest that 'some scholars' estimate as high as $400,000 .^{23}$ No doubt due to the book's popularity and certainly in keeping with the historic trend, the largest number offered by Ehrman has since been adopted by a number of authors including J. Harold Greenlee, Daniel B. Wallace, and Lee Martin McDonald. ${ }^{24}$ But even now, this number appears poised to be superseded by Eldon Epp's self-styled 'wild guess' of 400,000-750,000 variants, a number that marks what is, to date, both the highest estimate and the largest single increase from previous estimates. ${ }^{25}$

\subsection{Problems}

In his entertaining and helpful guide to spotting dubious data, Joel Best sums up his advice in one sentence: 'We need to be very careful when we can't tell who produced the figures, why, or how, and when we can't be sure whether consistent choices were made in the measurements at different times and places. ${ }^{26}$ Unfortunately, the estimates offered over the last 150 years all suffer from just these problems.

\footnotetext{
${ }^{18}$ H. J. Vogels and L. Pirot, 'Critique textuelle du Nouveau Testament,' Dictionnaire de la Bible: Supplément (ed. Louis Pirot; 13 vols.; Paris: Librairie Letouzey, 1934) II.226; Léon Vaganay, Initiation à la critique textuelle néotestamentaire (BCSR 6o ; Paris: Bloud et Gay, 1934) 9.

${ }^{19}$ Erwin Nestle, 'How to Use a Greek New Testament,' The Bible Translator 2, no. 2 (1951) 54.

${ }^{20}$ Kenneth W. Clark, 'The Theological Relevance of Textual Variation in Current Criticism of the Greek New Testament,' JBL 85 , no. 1 (1966) 12.

${ }^{21}$ Merrill M. Parvis, 'Text, NT,' The Interpreter's Dictionary of the Bible: An Illustrated Encyclopedia (ed. George Arthur Buttrick; 5 vols.; New York: Abingdon, 1962) IV.595; Clark, 'Theological Relevance,' 3.

${ }^{22} \mathrm{~J}$. K. Elliott and Ian Moir, Manuscripts and the Text of the New Testament: An Introduction for English Readers (Edinburgh: T\&T Clark, 1995) 21; Eldon Jay Epp, 'The Multivalence of the Term “Original Text” in New Testament Textual Criticism,' HTR (1999) 52; Ehrman, 'Text and Interpretation,' §8; Eckhard Schnabel, 'Textual Criticism: Recent Developments,' The Face of New Testament Studies: A Survey of Recent Research (ed. Scot McKnight and Grant R. Osborne; Grand Rapids: Baker Academic, 2004) 59.

${ }^{23}$ Eldon Jay Epp, 'It's All about Variants: A Variant-Conscious Approach to New Testament Textual Criticism,' HTR 100, no. 3 (2007) 275, 291; Bart D. Ehrman, Misquoting Jesus: The Story Behind Who Changed the Bible and Why (New York: Harper, 2005) 89.

${ }^{24}$ J. Harold Greenlee, The Text of the New Testament: From Manuscript to Modern Edition (Grand Rapids: Baker, 2008) 38; Daniel B. Wallace, 'Textual Criticism of the New Testament,' Lexham Bible Dictionary (ed. John D. Barry and Lazarus Wentz; Bellingham, WA: Lexham, 2012); Lee Martin McDonald, Formation of the Bible: The Story of the Church's Canon (Peabody, MA: Hendrickson, 2012) 144.

${ }^{25}$ Epp, 'Textual Criticism and New Testament Interpretation,' 87; Epp, 'Why Does New Testament Textual Criticism Matter?, 419 .

${ }^{26}$ Joel Best, Stat-Spotting: A Field Guide to Identifying Dubious Data (Berkeley: University of California Press, 2013) 124.
} 
In the first case, we often have no idea who produced the estimate. The use of the passive voice to introduce these numbers is rampant. Phrases like 'some say..${ }^{27}$ or 'one speaks of ... ${ }^{28}$ or 'it has been estimated that ...29 or there have been counted ... ${ }^{30}$ pave a long trail of unverified estimates. By citing the number this way, those who cite them are able to make use of the number while at the same time avoiding any real responsibility for it. The problem is made worse when the number is presented as one of 'the best estimates, ${ }^{31}$ 'competent estimates' (kundiger Schätzung), ${ }^{32}$ or the like. The impression on the reader is that someone somewhere has taken the trouble to work out a sound method of estimating; but no such source appears forthcoming.

Not surprisingly, the second problem is that those who cite these statistics never explain how they arrived at their estimate and this despite the fact that the numbers get repeated again and again in the literature. If we judge these estimates by The Chicago Guide to Writing about Numbers when it says that 'an essential part of writing about numbers is a description of the data and methods used to generate your figures, ${ }^{33}$ then all previous estimates must be deemed inadequate. Most estimates come with no rationale whatsoever, but even those few that do are problematic. Several estimates are offered as multiplications of Mill's 30,000 variants, but there is no rationale for the rate of multiplication given. Worse still, they fail to recognize that their starting number is itself an estimate. Warfield is unique in telling us how his numbers were 'counted,' but on this point there is every reason not to follow him. The most promising estimates of the bunch are those offered by Parvis and Clark because they were based on fresh collations of a significant number of manuscripts of Luke. But it turns out that neither estimate is based on a count of the variants found in the Luke collations, but only on an estimate of them, and precisely here they disagree. Whereas Parvis suggests that there are 30,000 variants in 150 of the 300 manuscripts collated, Clark estimates 25,000 variants among all 300 manuscripts. ${ }^{34}$ The fact that Clark derives fewer variants from more manuscripts suggests that something is amiss. This, of course, illustrates the broader problem of basing one estimate on another.

The third problem is that it is not always clear what is being estimated. Is it some differences among some witnesses, some differences among all witnesses, or all differences among all witnesses to the New Testament? Eldon Epp, for example, has elsewhere carefully distinguished 'textual readings' from 'textual variants' with the latter excluding all 'nonsense readings,' 'clearly demonstrable scribal errors,' 'orthographic differences,' and 'singular readings. ${ }^{35}$ But when it comes to his own 'wild guess' of 400,000-750,000, which of these does he have in mind? As with so many past estimates, the answer is not clear.

\footnotetext{
${ }^{27}$ Léon Vaganay and Christian-Bernard Amphoux, An Introduction to New Testament Textual Criticism (Cambridge: Cambridge University Press, 1991²) 2; Ehrman, Misquoting Jesus, 89 .

${ }^{28}$ Heide, 'Assessing,' 157.

${ }^{29}$ Elliott and Moir, Manuscripts, 21.

${ }^{30}$ Warfield, Introduction, 13.

${ }^{31}$ Ehrman, 'Text and Interpretation,' §8; Wallace, 'Lost in Transmission,' 20.

${ }^{32}$ Eberhard Nestle, Einführung in das Griechische Neue Testament (Göttingen: Vandenhoeck und Ruprecht, 1897) 14.

${ }^{33}$ Jane E. Miller, The Chicago Guide to Writing about Numbers (Chicago: University of Chicago Press, 2004) 200.

${ }^{34}$ Parvis, 'Text,' 595; Clark, 'Theological Relevance,' 3, 12. For comparison, David Parker estimates 11,00o variants in the nearly 2,00o Greek manuscripts of the Gospel of John. See David C. Parker, Textual Scholarship and the Making of the New Testament: The Lyell Lectures (Oxford: Oxford University Press, 2012) 84.

${ }^{35}$ Eldon Jay Epp, 'Textual Criticism (NT),' The Anchor Bible Dictionary (ed. David Noel Freedman; 6 vols.; New York: Doubleday, 1992) IV.413-14. For an extended discussion, see Eldon Jay Epp, "Toward the Clarification of the Term "Textual Variant," in Studies in the Theory and Method of New Testament Textual Criticism (Studies and Documents 45; Grand Rapids: Eerdmans, 1993) $47-61$.
} 


\section{PROPOSING A NEW ESTIMATE}

\subsection{Method \& Scope}

As any survey of bad statistics can, this one may induce the negative impression that all numbers are meaningless. But this would be unduly cynical. The truth is that the most important feature of good statistics is very simple: they are public. Public in the sense that 'we are told where they come from and how they were produced, but also public in the sense that dissenting views about methods might be taken into account and used to refine definitions and measurement choices. ${ }^{36}$ It is this quality above all that we attempt to provide in the estimate that follows.

\subsubsection{Who}

If any estimate is to be useful, it must clearly explain the who, the what, and the how that characterize all good statistics. The first is obviously the simplest. The estimate offered below is my own and therefore so is the credit or discredit for its quality.

\subsubsection{What}

In the second case, I limit my estimate to the number of variants found in the Greek manuscripts only (papyri, majuscules, minuscules, and lectionaries). This is not to disparage other witnesses such as the versions, patristic citations, inscriptions etc., but is simply due to the difficulties of translation technique, citation style, and, in many cases, the dearth of robust data.

The question of what we are counting is at once complex and simple. It is complex because any decision about what constitutes a difference between any two texts involves the subjectivity of human judgment. Yet it is simple in this particular case because I will be entirely dependent on the collations of others. In looking for good collations to work from I have chosen those that include the most data from the most witnesses in the most accessible form. ${ }^{37}$

The three main sources I have selected are Bruce Morrill's dissertation on John 18, Matthew Solomon's dissertation on Philemon, and Tommy Wasserman's work on Jude..$^{8}$ Each of these works offers some of the most extensive collation data available for the Greek New Testament. A fourth resource considered is the Text und Textwert series published from 1987-2005 by Kurt Aland and his colleagues at the Institut für neutestamentliche Textforschung. ${ }^{39}$ However, because the Text und Textwert volumes only provide

\footnotetext{
${ }^{36}$ Best, Stat-Spotting, 124 .

${ }^{37}$ This last criterion regrettably led to the exclusion of H. C. Hoskier's important work in Concerning the Text of the Apocalypse: Collations of All Existing Available Greek Documents with the Standard Text of Stephen's Third Edition, Together with the Testimony of Versions, Commentaries and Fathers. A Complete Conspectus of All Authorities, (2 vols.; London: Bernard Quaritch, 1929).

${ }^{38}$ M. Bruce Morrill, 'A Complete Collation and Analysis of All Greek Manuscripts of John 18' (PhD diss.; University of Birmingham, 2012); S. Matthew Solomon, 'The Textual History of Philemon' (PhD diss.; New Orleans Baptist Theological Seminary, 2014); Tommy Wasserman, The Epistle of Jude: Its Text and Transmission (Coniectanea Biblica New Testament Series 43; Stockholm: Almqvist \& Wiksell, 2006).

${ }^{39}$ Kurt Aland et al., eds., Text und Textwert der griechischen Handscriften des Neuen Testaments (16 vols.; ANTF; Berlin: Walter de Gruyter, 1987-2005).
} 
collations in select passages (or Teststellen), they will have to be used with care as will be explained in what follows. For comparison, the relevant features of each of these four sources are listed in Table $1 .^{40}$

\begin{tabular}{lllll}
\hline Collation Source & Manuscripts & Variants Included & Corpus & Coverage \\
\hline Bruce Morrill & All continuous text MSS & $\begin{array}{l}\text { All but the most common } \\
\text { spelling differences }\end{array}$ & John 18 & Entire chapter \\
Matthew Solomon & All continuous text MSS & All differences & Philemon & Entire book \\
\hline Tommy Wasserman & $\begin{array}{l}\text { All continuous text MSS } \\
\text { plus } 1 / 2 \text { of lectionaries }\end{array}$ & $\begin{array}{l}\text { All but the most common } \\
\text { spelling differences }\end{array}$ & Jude & Entire book \\
\hline Text und Textwert & All continuous text MSS & $\begin{array}{l}\text { All but nonsense readings } \\
\text { \& spelling differences }\end{array}$ & $\begin{array}{l}\text { Entire NT } \\
\text { except Rev }\end{array}$ & $\begin{array}{l}\text { Test passages only } \\
\text { (e.g., ll in Jude) }\end{array}$ \\
\hline
\end{tabular}

Table 1. A comparison of the extent of each collation.

The most important aspect of our estimate is, of course, the definition of the term 'variant.' So far we have used the words 'variant,' 'reading,' and 'difference' interchangeably and somewhat imprecisely. But if our estimate is to be useful, we need to be crystal clear about what it is we are estimating. Within the disciple of New Testament textual criticism, a number of attempts have been made to distinguish the terms 'variant' and 'reading,' but a consensus has yet to emerge. ${ }^{41}$ For the present purpose, I will restrict myself to the term 'textual variant' which I define as a word or concatenation of words in any manuscript that differs from any other manuscript within a comparable segment of text, excluding only spelling differences and different ways of abbreviating nomina sacra. ${ }^{42}$

Before moving on, two important observations should be made about this definition. First, this definition is relative to the manuscripts themselves rather than to any particular editorial text. ${ }^{43}$ This means that at any point of comparison where there are at least two readings, all of them are counted as 'variants,' even those that the collator or editor believes to be the original source of the other(s). In this context, then, 'original' and 'variant' are not mutually exclusive descriptors.

Second, notice should be taken of the important qualification 'comparable segment of text' in our definition. This phrase simply designates what textual critics normally refer to as a 'variant unit. ${ }^{\text {'4 }}$ Deciding

${ }^{40}$ For details, see Morrill, 'Complete Collation,' 63; Solomon, 'Textual History', 29-37; Wasserman, Jude, 129-13o; Kurt Aland, Barbara Aland, and Klaus Wachtel, eds., Text und Textwert der griechischen Handschriften des Neuen Testaments: V. Das Johannesevangelium: ı. Teststellenkollation der Kaptiel 1-10: Band 1, 1: Handschriftenliste und vergleichende Beschreibung (ANTF 35; Berlin: Walter de Gruyter, 2005) $7^{*}-8^{*}$.

${ }^{41}$ For representative discussions, see E. C. Colwell and Ernest W. Tune, 'Method in Classifying and Evaluating Variant Readings,' Studies in Methodology in Textual Criticism of the New Testament (NTTS 9; Leiden: Brill, 1969) 96-105; Epp, 'Clarification'; Gordon D. Fee, 'On the Types, Classification, and Presentation of Textual Variation,' Studies in the Methodology in Textual Criticism of the New Testament (Studies and Documents 45; Grand Rapids: Eerdmans, 1993) 62-79; David C. Parker, An Introduction to the New Testament Manuscripts and Their Texts (Cambridge: Cambridge University Press, 2008) 4-5; Barbara Aland et al., eds., Novum Testamentum Graecum: Editio Critica Maior IV: Catholic Letters (Stuttgart: Deutsche Bibelgesellschaft, $2013^{2}$ ) $26^{*}-7^{*}$.

${ }^{42}$ It should be noted here that, unlike Morrill and Wasserman, Solomon places differences between pronouns such as $\dot{u} \mu \hat{\omega} v / \dot{\eta} \mu \hat{\omega} \nu$ and $\alpha \dot{v} \tau 0 \hat{v} / \dot{\varepsilon} \alpha \nu \tau \odot \hat{v}$ in the category of 'spelling differences' (Solomon, 'Textual History,' 33). I counted 18 of these and have included them in what follows because, in my opinion, they should not be categorized as spelling differences.

${ }^{43}$ For this distinction, see especially, Epp, 'Clarification,' 50. Precisely because this definition is oriented to manuscripts rather than reconstructed texts, it avoids completely the debates about the identification of the 'original' text, on which see Michael W. Holmes, 'From 'Original Text' to 'Initial Text': The Traditional Goal of New Testament Textual Criticism in Contemporary Discussion,' The Text of the New Testament in Contemporary Research: Essays on the Status Quaestionis (ed. Bart D. Ehrman and Michael W. Holmes; NTTSD 42; Leiden: Brill, 2013²) 637-88.

${ }^{44}$ On the importance of the distinction between 'variant' and 'variant unit,' see Colwell and Tune, 'Method in Classifying,' 99100; Epp, 'Clarification,' 49-50, 60-1. 
exactly where to place the boundaries of comparable segments is a matter of human judgment and one that, significantly for our purposes, can affect the number of resulting variants. ${ }^{45}$ Exactly how much it may affect the overall results is hard to say with certainty, but my impression from working in multiple datasets is that the more complete the collation, the less effect such decisions have on the overall number of variants. In any case, it must be said that the following estimate is entirely dependent on the judgment of others when it comes to setting these boundaries.

\subsubsection{How}

Given these collation sources and our definition of what is to be counted, it remains to explain how we will arrive at our overall estimate for the entire New Testament. The first thing to note is that our estimate is not based on another estimate but instead on an actual count of textual variants. In this way, it differs from all previous estimates. Still, it is an estimate, and every estimate is essentially an extrapolation from one set of data to another. The simplest point of extrapolation in our case is the number of words in each book of the New Testament. Obviously this number depends on the edition we use but, so long as we use the same edition for each side of the formula, the results will be consistent. Because of its close relationship with the Text und Textwert volumes, I have chosen the 27th edition of the Nestle-Aland Novum Testamentum Graece which has 138,020 words including those in double and single brackets. ${ }^{46}$ If we know the number of variants per word in one section of text, or what we might call the 'rate of variation,' we can extrapolate from this to the New Testament as a whole. The formula is as follows:

$$
\frac{\text { Number of variants in the sample }(a)}{\text { Number of words in the sample in NA27 }(b)}=\frac{\text { Number of variants in the NT }(y)}{\text { Number of words in NA27 }(z)}
$$

Since we are interested in the number of variants in the New Testament $(y)$, we can arrange the formula as $z$ $(a \div b) \times z=y$.

To arrive at the rate of variation for each corpus, I carefully combed the selected collations and counted the variants in each one, noting nonsense or singular readings where possible. In some cases the count was aided by the availability of electronic datasets, but otherwise it was done by hand. The raw data from our three main sources are presented in

Table 2.

\begin{tabular}{lrrrrr}
\hline Book/Chapter & MSS Collated & Variant Units & Variants & Nonsense Variants & Singular Variants \\
\hline John 18(M) & 1,659 & 524 & 3,058 & 1,360 & 1,768 \\
\hdashline Philemon (S) & 572 & 293 & 1,185 & 218 & 409 \\
\hline
\end{tabular}

${ }^{45}$ An excellent discussion of the problem is given in Morrill, 'Complete Collation,' $55^{-65}$. For a good illustration, see Parker, Introduction, 4-5. For an explanation of how software can segment texts in the process of collation, see Peter Robinson, 'Rationale and Implementation of the Collation System Used on This CD-ROM,' The Miller's Tale on CD-ROM (Leicester: Scholarly Digital Editions, 2004), now available at http://www.sd-editions.com/AnaServer/?millerEx+3344574+text.anv (accessed October 2, 2014).

${ }^{46}$ This count was done electronically in Logos Bible Software. For comparison, the electronic text of Westcott and Hort has 137,655 words and the Robinson-Pierpont Byzantine text has 140,155. Using the more recent Nestle-Aland 28th edition would make little difference since it is shorter than the NA27 by only seven words (see Barbara Aland et al., eds., Novum Testamentum Graece (Stuttgart: Deutsche Bibelgesellschaft, 2012) $50^{*}-1^{*}$ ). 
Table 2. Data from the collations of Morrill (M), Solomon (S), and Wasserman (W).

To this data we can add a number of useful points of comparison such as the number of words and the number of variant units. We can also tabulate what percentage of total variants are nonsense and singular readings. These comparisons are given in Table 3 (rates are rounded up to the nearest hundredth and percentages to the nearest tenth).

\begin{tabular}{lrrrrr}
\hline Book/Chapter & $\begin{array}{r}\text { NA27 Words } \\
\text { in Book/Chapter }\end{array}$ & $\begin{array}{r}\text { Avg. Variants } \\
\text { per Variation Unit }\end{array}$ & $\begin{array}{r}\text { Avg. Variants } \\
\text { per Word }\end{array}$ & $\begin{array}{r}\text { Percent } \\
\text { Nonsense }\end{array}$ & $\begin{array}{r}\text { Percent } \\
\text { Singular }\end{array}$ \\
\hline John 18(M) & 791 & 5.84 & 3.87 & 44.5 & 57.8 \\
\hline Philemon (S) & 335 & 4.04 & 3.54 & 18.4 & 42.3 \\
Jude (W) & 461 & 5.23 & 3.67 & 29.6 & 50.7 \\
\hline AVERAGE & - & $\mathbf{5 . 0 4}$ & $\mathbf{3 . 6 9}$ & $\mathbf{3 0 . 8}$ & $\mathbf{5 0 . 3}$ \\
\hline
\end{tabular}

Table 3. A comparison of the number of variants to the number of variation units and the number of words. The last column shows the percentage of variants that are nonsensical or that only occur in one of the collated manuscripts.

Before proceeding to our estimate, a few observations are worth making. First, the percentage of singular variants is especially high, averaging just over half of all variants across the three collations and reaching nearly 60 percent in John 18 . The percentage of nonsense variants is not as high but still significant, averaging over 30 percent across the three collations and reaching nearly 45 percent in John 18. Not surprisingly, these last two categories show substantial overlap so that 86.3 percent of all nonsense variants in John 18 are also singular variants. In Philemon the percentage is 64.2 and in Jude it reaches 84.7 percent. This confirms that obvious mistakes were the easiest kind for scribes to spot and then correct.

Second, we should consider the relationships between the number of variants and the number of manuscripts. It is true, as Bentley knew, that collating more manuscripts increases the number of variants. But we can also say that the increase is not linear or exponential but rather logarithmic. This is because the majority of manuscripts are Byzantine which means they are also the most uniform. As more Byzantine manuscripts are collated, they individually contribute fewer and fewer variants. We can see this first of all by noting that the rate of variation (or words-to-variants) is very close between the three collations despite the fact that John 18 has almost three times the number of manuscripts. The reason is that so many of these additional manuscripts are Byzantine. We can observe the same effect if we compare Wasserman's collation of Jude to that of the Editio Critica Maior $(E C M) .{ }^{47}$ Although Wasserman collated more than triple the number of witnesses, the result was less than double the number of total variants. ${ }^{48}$ The reason is the same: when it comes to Byzantine manuscripts and the number of textual variants, the law of diminishing returns sets in. ${ }^{49}$

\footnotetext{
${ }^{47}$ My thanks to Klaus Wachtel for providing the electronic datasets behind the $E C M^{2}$.

${ }^{48}$ Wasserman: 560 manuscripts and 1,694 variants; $E C M^{2}: 156$ manuscripts and 789 variants.

${ }^{49}$ As medievalist Paolo Trovato observes, 'The number of variants seems to be directly proportional to the number of surviving witnesses, but their increase tends to stabilize, following a saturation curve, once most of the witnesses have been collated' (Everything You Always Wanted to Know about Lachmann's Method: A Non-Standard Handbook of Genealogical Textual Criticism in the Age of Post-Structuralism, Cladistics, and Copy-Text (Storie e linguaggi; Padova: Libreriauniversitaria.it, 2014) 62).
} 


\subsection{A Proposed Estimate}

Based on these numbers, we are now in a position to estimate the total number of variants in the Greek New Testament. Our formula again is (Number of variants in the sample $\div$ Number of words in sample) $\times$ Number of words in NA27 = Estimated number of variants in the New Testament.

$$
\begin{array}{ll}
\text { Morrill } & (3,058 \div 791) \times 138,020=533,584 \\
\text { Solomon } & (1,185 \div 335) \times 138,020=488,220 \\
\text { Wasserman } & (1,694 \div 461) \times 138,020=507,171
\end{array}
$$

Given that these estimates are based on collations from a range of the New Testament (Gospels, Pauline Epistles, and Catholic Epistles), they are remarkably similar. If they have a shortcoming, however, it is that they assume a constant rate of variation across the entire New Testament. In order to let the transmission of each book have its due, we could use the data from the Text und Textwert volumes, being aware that they

\begin{tabular}{|c|c|c|c|c|}
\hline Book & MSS Collated & Teststellen & Variants & Singular Variants \\
\hline Matthew & 1,657 & 64 & 720 & 346 \\
\hline Mark & 1,660 & 196 & 2,431 & 1,144 \\
\hline Luke & 1,672 & 54 & 862 & 413 \\
\hline John 1-10 & 1,683 & 153 & 1,306 & 439 \\
\hline Acts & 486 & 104 & 1,260 & 616 \\
\hline Romans & 601 & 47 & 475 & 223 \\
\hline 1 Corinthians & 605 & 59 & 660 & 260 \\
\hline 2 Corinthians & 612 & 26 & 392 & 201 \\
\hline Galatians & 609 & 17 & 235 & 99 \\
\hline Ephesians & 607 & 18 & 181 & 80 \\
\hline Philippians & 609 & 11 & 146 & 71 \\
\hline Colossians & 612 & 10 & 127 & 59 \\
\hline 1 Thessalonians & 598 & 5 & 53 & 26 \\
\hline 2 Thessalonians & 598 & 4 & 58 & 24 \\
\hline 1 Timothy & 597 & 9 & 90 & 40 \\
\hline 2 Timothy & 586 & 5 & 43 & 19 \\
\hline Titus & 574 & 3 & 67 & 35 \\
\hline Philemon & 563 & 4 & 65 & 35 \\
\hline Hebrews & 595 & 33 & 307 & 127 \\
\hline James & 517 & 25 & 174 & 60 \\
\hline 1 Peter & 519 & 13 & 121 & 46 \\
\hline 2 Peter & 511 & 14 & 141 & 55 \\
\hline 1 John & 504 & 23 & 205 & 84 \\
\hline 2 John & 490 & 8 & 52 & 24 \\
\hline
\end{tabular}
offer data only in the 920 test passages (Teststellen) and that they do not include any nonsense variants. ${ }^{50}$ The data from these volumes is presented in Table 4 and Table 5 .

${ }^{50}$ The exception is the final volume on John $1-10$ which records both nonsense and orthographic variants. With the exception of Table 6, we leave these variants out for consistency. 


3 John
Jude

Table 4. The number of manuscripts is taken from the test passage in each book with the most number of witnesses cited. Omissions that result from either homoeoteleuton or homoeoarchton (designated with ' $U$ ' or ' $V$ ' in the apparatus) are counted only where they result in a distinct reading within their variation unit. When multiple such omissions occur in the same variation unit, they are not counted as singular readings. Manuscripts that omit all of Mark 16.9-20 or John 7.53-8.11 are not re-counted in subsequent variation units within these passages. A dash marks unavailable data.

\begin{tabular}{|c|c|c|c|c|}
\hline Book & $\begin{array}{l}\text { NA27 Words } \\
\text { in Test Passages }\end{array}$ & $\begin{array}{r}\text { Avg. Variants } \\
\text { per Test Passage }\end{array}$ & $\begin{array}{l}\text { Avg. Variants } \\
\text { per Word }\end{array}$ & $\begin{array}{l}\text { Percent } \\
\text { Singular }\end{array}$ \\
\hline Matthew & 156 & 11.25 & 4.62 & 48.1 \\
\hline Mark & 506 & 12.40 & 4.80 & 47.1 \\
\hline Luke & 167 & 15.96 & 5.16 & 47.9 \\
\hline John 1-10 & 377 & 8.54 & 3.46 & 33.6 \\
\hline Acts & 310 & 12.12 & 4.06 & 48.9 \\
\hline Romans & 126 & 10.11 & 3.77 & 46.9 \\
\hline 1 Corinthians & 201 & 11.19 & 3.28 & 39.4 \\
\hline 2 Corinthians & 108 & 15.08 & 3.63 & 51.3 \\
\hline Galatians & 48 & 13.82 & 4.90 & 42.1 \\
\hline Ephesians & 46 & 10.06 & 3.93 & 44.2 \\
\hline Philippians & 40 & 13.27 & 3.65 & 48.6 \\
\hline Colossians & 24 & 12.70 & 5.29 & 46.5 \\
\hline 1 Thessalonians & 10 & 10.60 & 5.30 & 49.1 \\
\hline 2 Thessalonians & 15 & 14.50 & 3.87 & 41.4 \\
\hline 1 Timothy & 17 & 10.00 & 5.29 & 44.4 \\
\hline 2 Timothy & 9 & 8.60 & 4.78 & 44.2 \\
\hline Titus & 9 & 22.33 & 7.44 & 52.2 \\
\hline Philemon & 14 & 16.25 & 4.64 & 53.8 \\
\hline Hebrews & 74 & 9.30 & 4.15 & 41.4 \\
\hline James & 61 & 6.96 & 2.85 & 34.5 \\
\hline 1 Peter & 21 & 9.31 & 5.76 & 38.0 \\
\hline 2 Peter & 44 & 10.07 & 3.20 & 39.0 \\
\hline 1 John & 81 & 8.91 & 2.53 & 41.0 \\
\hline 2 John & 9 & 6.50 & 5.78 & 46.2 \\
\hline 3 John & 7 & 5.50 & 3.14 & 36.4 \\
\hline Jude & 51 & 15.45 & 3.33 & 49.4 \\
\hline Revelation & - & - & - & - \\
\hline AVERAGE & - & 11.57 & 4.33 & $44.4 \%$ \\
\hline
\end{tabular}

Table 5. A comparison of the number of variants to the number of words and variation units in Text und Textwert. The word counts are taken from the primary line text of each test passage (marked in TuT by an underline). 
To ensure that each book's transmission is treated separately, we applied our formula to each book individually and only then added the totals together. ${ }^{51}$ The result is the highest estimate so far: 591,044 variants for the entire New Testament. Comparing this with the other three estimates, it is striking that the more expansive collations result in lower estimates. How could this be? One explanation might be that John 18, Philemon, and Jude were more carefully copied than other parts of the New Testament and therefore exhibit below average rates of variation as compared with the rest of the New Testament. The more likely explanation is found in the selective nature of the Text und Textwert test passages which may not be as representative of the amount of variation as we might hope. The test passages were not, after all, chosen at random, but were 'carefully selected' for the specific purpose of evaluating a manuscript's textual worth (Textwert $).{ }^{52}$ In fact, we do not need to hypothesize this explanation; we can demonstrate it by comparing the overlapping data in Table 6.

\begin{tabular}{|c|c|c|c|c|c|c|}
\hline Collation & MSS Collated & NA27 Words & Variation Units & Variants & $\begin{array}{l}\text { Avg. Variants } \\
\text { per Unit }\end{array}$ & $\begin{array}{r}\text { Avg. Variants } \\
\text { per Word }\end{array}$ \\
\hline John 1-10 (TuT) & 1,683 & 377 & 153 & 1,570 & 10.26 & 4.16 \\
\hline John 18 (M) & 1,659 & 791 & 524 & 3,058 & 5.84 & 3.87 \\
\hline Philemon (TuT) & 563 & 14 & 4 & 65 & 16.25 & 4.64 \\
\hline Philemon (S) & 572 & 335 & 293 & 967 & 3.30 & 2.89 \\
\hline Jude (TuT) & 499 & 51 & 11 & 170 & 15.45 & 3.33 \\
\hline Jude (W) & 560 & 461 & 324 & 1,192 & 3.68 & 2.59 \\
\hline
\end{tabular}

Table 6. A comparison of data from Text und Textwert (TuT) and from Morrill (M), Solomon (S), and Wasserman (W). Nonsense readings are here excluded from Solomon and Wasserman's data and included for the TuT data for John 1-10.

In all three cases, the Text und Textwert test passages show above average rates of variation. In the case of John, there are 0.29 more variants per word in the John 1-10 test passages than in Morrill's John 18 collation; in Jude, the rate is 0.74 more variants per word in the test passages; and particularly striking, in Philemon the rate is 1.75 more variants per word. This means that if we were to use the Text und Textwert test passages to estimate the number of variants in all of Philemon and Jude, our estimate would overshoot the actual number of variants by more than 580 and 350, respectively. The difference might seem slight, but if the same rate of overestimation held across the New Testament, the result would be 100,000-240,000 variants too many. Event still, our estimate would not be wildly off the mark, and the benefit of having data from each individual book means that we should not discard the Text und Textwert estimate completely.

We suggest that a reasonable estimate for the number of textual variants in the Greek New Testament (not including spelling differences) is about 500,000. This estimate-and we emphasize that it is still an estimate - is based on a sample size of about three percent of the entire Greek New Testament and includes minuscules, majuscules, and some lectionaries. Except for Revelation, it is based on data from portions of

\footnotetext{
${ }^{51}$ The estimates for each book are Matt: 84,759; Mark: 54,259; Luke: 100,527; John: 54,097; Acts: 74,907; Rom: 26,808 ; 1 Cor: 22,402; 2 Cor: 16,252; Gal: 10,927; Eph: 9,518; Phil: 5,946; Col: 8,369; 1 Thess: 7,849; 2 Thess: 3,185; 1 Tim: 8,416; 2 Tim: 5,918; Titus: 4,903; Philm: 1,554; Heb: 20,555; Jas: 4,965; 1 Pet: 9,700; 2 Pet: 3,517; 1 John: 5,417; 2 John: 1,416; 3 John: 688; Jude: 1,535; Rev: 42,655. Because no data are available for Revelation in TuT, we have averaged the rate of variation in the other 26 books (= 4.33).

${ }^{52}$ Kurt Aland and Barbara Aland, The Text of the New Testament: An Introduction to the Critical Editions and to the Theory and Practice of Modern Textual Criticism (Grand Rapids: Eerdmans, $1989^{2}$ ) 318 . This would also explain the much higher rate of variants per variation unit.
} 
every book and therefore does not assume that all books were copied with the same frequency or the same accuracy. It does not include variants from patristic citations, versions, amulets, or inscriptions.

\section{THE VALUE OF THE ESTIMATE}

If the preceding estimate is reasonable, what is its value? Some might suggest that there is no value whatsoever. Kenneth Clark is convinced, for example, that 'counting words is a meaningless measure of textual variation, and all such estimates fail to convey the theological significance of variable readings. ${ }^{53} \mathrm{We}$ may agree with the second claim without agreeing with the first. There is no reason to be so pessimistic that counting and estimating can tell us nothing at all about the overall transmission of the New Testament; we simply need to be careful how we use the data.

By way of negative example, we might be tempted to compare our estimate to the number of extant manuscripts as Craig Blomberg and Stanley Porter have done. ${ }^{54}$ In that case we could conclude that each of our 5,60o manuscripts contributes, on average, only 90 variants. But a moment's reflection reminds us that our Greek manuscripts are of such widely varying length that this is a meaningless comparison-just think of 90 variants in Codex Sinaiticus and $\mathrm{P}_{52}$ alike. What if we used pages instead of manuscripts as our unit of comparison? The homepage for the New Testament Virtual Manuscript Room (NTVMR) currently lists the number of catalogued pages for the Greek New Testament at 2,111,770 pages. ${ }^{55}$ This would mean, on average, about one variant for every four pages; or 0.25 variants per page. Unfortunately, we still have the problem that a page is not a stable unit of comparison since pages vary both in size and in the amount of text they contain without any necessary correlation between the two. It is, after all, in the process of copying words that scribes introduce variants, not in trimming pages or in binding them together.

As a further example, comparison has often been made between the number of variants and the number of words in the New Testament (presumably in some particular edition). ${ }^{56}$ This leaves one with more variants than there are words, a view of the matter which some seem to find particularly appealing for its 'shock value.' Despite its popularity, this comparison may be the most dubious, at least if it is intended to tell us anything about the transmission of the New Testament. The reason is that it completely fails to recognize that the same process that introduces variants into a textual tradition (i.e., copying) also increases the total number of words that thereby attest to that very same textual tradition. As with the other comparisons considered, this one fails to recognize that scribes introduce variants only in the process of writing. As before the result is a false comparison.

Can we, then, say anything meaningful about textual transmission of the New Testament based on the number of estimated variants? We can if we compare the number of variants in our manuscripts, not with the number of manuscripts, pages, or words in the New Testament, but instead with the number of words in the manuscripts from which the variants derive. Unfortunately, no one knows the number of words in our

\footnotetext{
${ }^{53}$ Clark, 'Theological Relevance,' 5 . In a similar vein, Bart Ehrman says of his 'Orthodox corruptions' that 'it is pointless ... to calculate the numbers of words of the New Testament affected by such variations' (Bart D. Ehrman, The Orthodox Corruption of Scripture: The Effect of Early Christological Controversies on the Text of the New Testament (New York: Oxford University Press, 2003) 276). For a response, see Heide, 'Assessing,' 125-59, esp. 155.

${ }^{54}$ Porter, How We Got the New Testament, 66; Blomberg, Can We Still Believe?, 17.

${ }^{55}$ See http://ntvmr.uni-muenster.de (accessed 5 February, 2015).

${ }^{56}$ Examples are found in Eberhard Nestle, Einführung, 14; Vogels and Pirot, 'Critique textuelle,' II.262; Erwin Nestle, 'How to Use,' 54; Otto Stegmüller, 'Überlieferungsgeschichte der Bibel,' Die Textüberlieferung der antiken Literatur und der Bibel (München: Deutscher Taschenbuch, 1975') 195; Ehrman and Wallace, 'Textual Reliability,' 21, 32-3; Clinton S. Baldwin, 'Factor Analysis: A New Method for Classifying New Testament Greek Manuscripts,' Andrews University Seminary Studies 48, no. 1 (2010) 29.
} 
extant manuscripts and probably no one will for some time still. Nevertheless, we can make such a comparison on a small scale with our data from our three main collation sources. If, for example, we assume that all 1,659 manuscripts collated for John 18 have somewhere between the NA27's 791 words and Robinson-Pierpont's 801 words, this would tell us that scribes contributed, on average, roughly one new variant for every 430 words they copied. This is only slightly lower than what David Parker calculates for two very close members of family 1 in Matthew: one variant for every $55^{0}$ words. ${ }^{57}$ Turning to Philemon and Jude, the rate drops significantly to about one variant for every 150 words copied in both cases. As before, the difference is surely attributable to the smaller number of Byzantine manuscripts of Philemon and Jude. In all three cases, however, the data confirm that the large number of variants is a reflection of the frequency with which scribes copied more than a reflection of their failure to do so faithfully. ${ }^{5}$

Another way our proposed estimate is helpful is that it is founded on qualitative and not merely quantitative data. We can say, for example, that almost $5^{0}$ percent of our estimated variants are the kinds that many textual critics would deem to be the least likely to be original, namely, singular readings. We can go further and note that in John 18, 44 percent of all variants are such that the editor could not make sense of either logically or grammatically (i.e., 'nonsense' variants). In Philemon and Jude, the rates are lower but still amounts to 18 and 29 percent, respectively. This simply confirms what seasoned textual critics have always known and that is that a significant percentage of the variants in our manuscripts have little or no claim to being original.

\section{CONCLUSION}

Roughly 150 years after Mill's edition was published with its estimated 30,000 variants, Scrivener suggested that the number should be quadrupled. Now, more than over 150 years after Scrivener, we can more than quadruple Scrivener's estimate, although we do so with reference to Greek manuscripts alone. We can also say that all previous estimates have been too low, especially those that claim to include variants from versional and patristic sources. The exception is Eldon Epp's 'wild guess' of up to 750,00o which is probably too high, even with the inclusion of patristic and versional evidence. Most importantly, our estimate allows scholars to avoid passing the responsibility for their estimates to silent and invisible sources. The present estimate is based on a clear foundation in the available data and a clear method, both of which are open to public scrutiny. One hopes that these two qualities alone will be enough to discourage all of us from the continued rehashing of unverified and unverifiable information about the transmission of the Greek New Testament. $^{59}$

${ }^{57}$ The manuscripts are the minuscules 1 and 1582. See Parker, Introduction, 137.

${ }^{58}$ As David Parker puts it, 'The extent of variation is related to the frequency of copying, so that comparatively rare change could, across many manuscripts, amount to the degree of variation that exists' ('Variants and Variance,' Texts and Traditions: Essays in Honour of J. Keith Elliott (ed. Peter Doble and Jeffery Kloha; NTTSD 47; Leiden: Brill, 2014) 34). Samuel Tregelles likewise explained the large number of variants as being 'partly from the frequency with which the New Testament was transcribed, and partly from the great number of copies which have come down to us' (Thomas H. Horne, John Ayre, and Samuel P. Tregelles, An Introduction to the Critical Study and Knowledge of the Holy Scriptures (4 vols.; London: Longmans, Green, \& Co., 1869) IV.48).

${ }^{59}$ Of those who read drafts of this paper, Peter M. Head, Dirk Jongkind, Peter D. Myers, and Daniel B. Wallace deserve special mention for their feedback. 


\section{APPENDIX: SURVEY OF ESTIMATES}

The following list offers a survey of estimates in New Testament introductions, dictionary and encyclopedia articles, exegetical handbooks, books on New Testament textual criticism, and books about the origin and formation of the Bible from the last 150 years. Where an author has been cited in the main text, only partial bibliography is given here.

\begin{tabular}{|c|c|c|c|}
\hline Scholar & Estimate & Date & Source \\
\hline Scrivener, F. H. A. & at least 120,000 & 1861 & Plain Introduction, 3 \\
\hline Schaff, Philip & $15^{0,000}$ & 1883 & Companion, 176 \\
\hline Dickson, William P. & 120,000 & 1886 & $\begin{array}{l}\text { 'New Testament,' The Imperial Bible-Dictionary: Historical, Biographical, } \\
\text { Geographical, and Doctrinal (ed. Patrick Fairbairn; London: Blackie \& } \\
\text { Son) } 370\end{array}$ \\
\hline Warfield, B.B. & $180,000-200,000$ & 1889 & Introduction, 13 \\
\hline $\begin{array}{l}\text { Abbot, Ezra, C. von } \\
\text { Tischendorf, and O. von } \\
\text { Gebhardt }\end{array}$ & 150,000 & 1891 & 'Bible Text-New Testament,' I.278 \\
\hline Nestle, Eberhard & $120,000-150,000$ & 1897 & Einführung, 14 \\
\hline Vincent, Marvin & $150,000-200,000$ & 1899 & History of the Textual Criticism, 6 \\
\hline Jülicher, Adolf & 30,000 or 100,000 & 1904 & Introduction to the New Testament, 589 \\
\hline Price, Ira Maurice & 150,000 & 1907 & $\begin{array}{l}\text { The Ancestry of Our English Bibles: An Account of Manuscripts, Texts, and } \\
\left.\text { Versions of the Bible (New York: Harper \& Brothers }{ }^{1}\right) 201\end{array}$ \\
\hline Sitterly, Charles & 200,000 & 1915 & 'Text and MSS (NT),' V.2955 \\
\hline $\begin{array}{l}\text { Pirot, Louis and H. J. } \\
\text { Vogels }\end{array}$ & 'près de 250,00o' & 1934 & ‘Critique textuelle,' II.262 \\
\hline Vaganay, Léon & $150,000-250,000$ & 1934 & Initiation, 9 \\
\hline Zuntz, Günther & $\begin{array}{l}\text { 'unimaginable \& } \\
\text { unmanageable mass' }\end{array}$ & $\begin{array}{l}{[1946]} \\
1953\end{array}$ & Text of the Epistles, $5^{8}$ \\
\hline Nestle, Erwin & $250,000-300,000$ & 1951 & 'How to Use a Greek New Testament,' 54 \\
\hline Parvis, Merrill M. & $\begin{array}{l}\text { 'much higher' than } \\
150,000-250,000\end{array}$ & 1962 & 'Text, NT,' 595 \\
\hline Clark, Kenneth W. & 300,000 & 1962 & $\begin{array}{l}\text { 'The Textual Criticism of the New Testament, Peake's Commentary on the } \\
\text { Bible (ed. Matthew Black and H. H. Rowley; London: Thomas Nelson) } 669\end{array}$ \\
\hline Clark, Kenneth W. & 300,000 & 1966 & 'Theological Relevance,' 3, 12 \\
\hline Collins, Raymond F. & 200,000 & 1983 & Introduction to the New Testament (New York: Doubleday) 77 \\
\hline Stenger, Werner & 250,000 & $\begin{array}{l}1993 \\
{[1987]}\end{array}$ & Introduction to New Testament Exegesis (Grand Rapids: Eerdmans) 13-14 \\
\hline Holmes, Michael W. & $\begin{array}{l}\text { Tens or even } \\
\text { hundreds of } \\
\text { thousands }\end{array}$ & 1991 & $\begin{array}{l}\text { 'Textual Criticism,' New Testament Criticism and Interpretation (ed. David } \\
\text { Alan Black and David S. Dockery; Grand Rapids: Zondervan) } 128 \text { n. } 21\end{array}$ \\
\hline $\begin{array}{l}\text { Vaganay, Léon and C.-B. } \\
\text { Amphoux }\end{array}$ & $150,000-250,000$ & 1991 & Introduction, 2 \\
\hline $\begin{array}{l}\text { Elliott, Keith and Ian } \\
\text { Moir }\end{array}$ & 300,000 & 1995 & Manuscripts and the Text, 21 \\
\hline Epp, Eldon J. & 300,000 & 1997 & $\begin{array}{l}\text { 'Textual Criticism in the Exegesis of the New Testament, with an } \\
\text { Excursus on Canon, A Handbook to the Exegesis of the New Testament (ed. } \\
\text { Stanley E. Porter; Leiden: Brill) } 5^{2-53}\end{array}$ \\
\hline Ehrman, Bart D. & 300,000 & 1997 & Kenneth W. Clark Lectures, 'Lecture One,' §8 \\
\hline
\end{tabular}




\begin{tabular}{|c|c|c|c|}
\hline Epp, Eldon J. & 300,000 & 1999 & 'Multivalence,' 277 \\
\hline $\begin{array}{l}\text { Piñero, Antonio and Jesús } \\
\text { Sáenz }\end{array}$ & 250,000 & 2003 & $\begin{array}{l}\text { The Study of the New Testament: A Comprehensive Introduction (Leiden: } \\
\left.\text { Deo, } 2003^{3}\right) 84\end{array}$ \\
\hline Schnabel, Eckhard J. & 300,000 & 2004 & ‘Textual Criticism,' 59 \\
\hline Epp, Eldon J. & $1 / 3$ million & 2007 & 'All About Variants,' 275, 291 \\
\hline Ehrman, Bart D. & $200,000-400,000$ & 2005 & Misquoting Jesus, 89 \\
\hline Wallace, Daniel B. & $300,000-400,000$ & 2006 & $\begin{array}{l}\text { 'Laying a Foundation: New Testament Textual Criticism,' Interpreting the } \\
\text { New Testament Text: Introduction to the Art and Science of Exegesis (ed. } \\
\text { Darrell L. Bock and Buist M. Fanning; Wheaton: Crossway) } 34\end{array}$ \\
\hline Greenlee, J. Harold & 400,000 & 2008 & Text of the New Testament, 38 \\
\hline Baldwin, Clinton & 300,000 & 2010 & 'Factor Analysis,' 29 \\
\hline Epp, Eldon J. & $400,000-750,000$ & 2011 & 'Textual Criticism and New Testament Interpretation,' 87 \\
\hline Wallace, Daniel B. & 400,000 & 2012 & 'Textual Criticism of the New Testament,' np \\
\hline McDonald, Lee Martin & $200,000-400,000$ & 2012 & Formation of the Bible, 129, 144 \\
\hline Porter, Stanley E. & $\begin{array}{l}\text { Over } 100,000 \\
\text { (up to } 400,000 \text { ) }\end{array}$ & 2013 & How We Got the New Testament, 23, 65 \\
\hline Blomberg, Craig L. & $200,000-400,000$ & 2014 & Can We Still Believe the Bible?, $16-17,27$ \\
\hline Epp, Eldon J. & $400,000-750,000$ & 2014 & 'Why Does New Testament Textual Criticism Matter?', 419 \\
\hline
\end{tabular}

